\title{
NOTE ON THE BACTERIOLYSIS OF GELATIN.
}

By Dr. S. Rideal, D.Sc., and R. Orchard.

(Read at the Meeting, June 2, 1897.)

IN ordinary bacteriological work for water analysis and other purposes, free use is made of gelatin media, and one of the distinctions between bacteria is founded on their liquefying, or not liquefying, gelatin. The jelly runs down the test-tube or collects on the surface of the plate, and forms a pool, which is fluorescent, or colored, or possessed of odours, according to the nature of the pure culture present.

Although an amount of work has been published on the changes resulting from the decomposition of various organic matters, especially albumin, no record of any experiments, or series of experiments, could be found which demonstrated quantitatively the chemical changes that take place when the ordinary gelatin medium used in bacteriological investigations is liquefied; in fact, the published analyses of commercial gelatin itself were very imperfect.

With the object, therefore, of determining the changes produced when gelatin is in process of liquefaction by bacteria, we have made a series of experiments on the following lines :

A quantity of gelatin medium was prepared, containing 10 per cent. of "Coignet's best gelatin" and 10 per cent. of Pasteur's solution, made up with Rochelle salts in the place of ammonium tartrate, in order to avoid the introduction of ready-formed ammonia; this was made faintly alkaline with sodium carbonate, and clarified in the usual manner. After heating the solution to $30^{\circ} \mathrm{C}$, so as to be quite fluid, quantities of 20 c.c. were pipetted into $6 \mathrm{oz}$. conical flasks, plugged with cotton-wool, and subsequently sterilized by heating to $100^{\circ} \mathrm{C}$. on three successive days. These were then inoculated from an active culture of the organism, and incubated at " room temperature" for the given time. Conical flasks were employed, in order that the liquefaction of the gelatin should proceed at the maximum rate, 
and consequently the organisms were cultivated as far as possible under aerobic conditions. Petri's dishes were tried, but, owing to the difficulty of manipulation without loss when the medium was fluid, they were abandoned. The different flasks showed progressive liquefaction of the gelatin according to time. The liquid produced was in all cases alkaline, had a slight putrefactive odour, was turbid, and contained no sulphuretted hydrogen.

In the subsequent analyses, after the different periods, the contents of the flasks were warmed to the same temperature $-30^{\circ} \mathrm{C}$.- - rendered faintly acid with acetic acid, and heated to $100^{\circ} \mathrm{C}$., in order to ascertain whether the bacteria in their growth had produced any weighable quantity of cellulose or coagulable albumin. No precipitate was obtained which could be estimated, except in one case-the sixteen days' culture of $B$. fluorescens liquefaciens, when the precipitate by heat amounted to 0.06 per cent. $(=0.01 \mathrm{~N})$. The contents of the flasks were cooled again to $30^{\circ} \mathrm{C}$., diluted with sterile water to 250 c.c., and aliquot portions carefully measured out at this temperature for each determination. In this way strictly comparative results were obtained, independent of the slight evaporation from the gelatin medium. The results were controlled in each case by a determination of the total nitrogen.

The gelatin and albumoses were estimated by Kühne and Chittenden's method of precipitation with saturated ammonium sulphate solution, dissolving the precipitate in warm water, dividing, and determining the total nitrogen in one portion, and in the other, very exactly, the $\mathrm{SO}_{3}$, then subtracting the nitrogen due to ammonium sulphate, a process which we prefer to that of direct weighing of the precipitate.

The albumoses were determined separately by precipitating a portion of the original solution with Stutzer's reagent (an emulsion of copper hydroxide in glycerin and water), washing, and estimating the nitrogen in the precipitate.

The volatile bases were estimated in a portion of the original, by distillation with caustic soda and titration of the distillate. A further portion of the original was precipitated with alcohol, filtered, and the nitrogen content of the filtrate returned as bases and extractives.

The two liquefying organisms selected were: (i.) B. prodigiosus, from an active gelatin culture, and (ii.) B. fluorescens liquefaciens, freshly obtained from tapwater. P. F. Frankland describes a gelatin-tube culture of $B$. prodigiosus in the following words: "Grows very rapidly, liquefying the gelatin in the form of a conical sack, which soon extends across the top of the tube, and, gradually passing downwards, involves the whole tube. The liquid is very turbid, with an abundant flocculent deposit of intense crimson colour." And a stab eulture of B. fluorescens liquefaciens (Flügge) as under: "In the path of the needle there is a whitish growth, whilst a funnel-shaped depression, containing liquid gelatin, forms on the surface; the liquefaction gradually stretches across the tube, and finally the whole contents are fluid and of a fluorescent green colour, whilst a white deposit collects." In the initial plate cultivations, after fourteen days at $20^{\circ}$ to $21^{\circ} \mathrm{C}$, , the gelatin was found to be only partially liquefied by the $B$. prodigiosus, so that our attention was chiefly confined to $B$. fluorescens liquefaciens. A number of flasks were inoculated with this organism, the contents being analysed after one day, when only a superficial liquefaction of the gelatin had taken place; two days, when about half had been liquefied; 
three and a half days, when the liquefaction of the gelatin was quite complete; and finally after sixteen days.

The following is a tabulated summary of the results obtained :

Calculated as Grammes of Nitrogen per 100 c.c.

\begin{tabular}{|c|c|c|c|c|c|c|c|c|}
\hline Incubated at $20^{\circ}$ to $21^{\circ} \mathrm{C}$. & $\begin{array}{c}\text { Total } \\
\text { Nitro- } \\
\text { gen. }\end{array}$ & $\begin{array}{l}\text { Gelatin } \\
\text { and } \\
\text { Albu- } \\
\text { moses. }\end{array}$ & $\begin{array}{l}\text { Albu- } \\
\text { moses. }\end{array}$ & $\begin{array}{l}\text { Ammo- } \\
\text { nia and } \\
\text { Volatile } \\
\text { Bases. }\end{array}$ & $\begin{array}{c}\text { Bases } \\
\text { and } \\
\text { Extrac- } \\
\text { tives. }\end{array}$ & $\begin{array}{l}\text { Peptone } \\
\text { N unac- } \\
\text { counted } \\
\text { for. }\end{array}$ & $\begin{array}{c}\text { Gela- } \\
\text { tin. }\end{array}$ & $\begin{array}{c}\text { Albu- } \\
\text { min and } \\
\text { Cellu- } \\
\text { lose. }\end{array}$ \\
\hline Blank (i.) & $1 \cdot 242$ & $1 \cdot 109$ & 0.514 & 0.003 & $0 \cdot 061$ & 0.069 & 0.595 & \\
\hline , (ii.) $\ldots$ & $1 \cdot 246$ & - & 0.528 & $0 \cdot 004$ & 一 & - & 0.581 & \\
\hline B. prodigiosus, 14 days ... & $1 \cdot 232$ & $1 \cdot 024$ & $0 \cdot 409$ & 0.049 & 一 & 一 & $0 \cdot 615$ & \\
\hline B. fluor. liquefaciens, 1 day & $1 \cdot 33$ & $1 \cdot 141$ & $0 \cdot 402$ & $0 \cdot 028$ & - & - & $0 \cdot 739$ & \\
\hline 2 days & $1 \cdot 256$ & $0 \cdot 682$ & $0 \cdot 297$ & $0 \cdot 045$ & $0 \cdot 105$ & $0 \cdot 424$ & 0.385 & \\
\hline $3 \frac{1}{2}$, & $1 \cdot 267$ & $0 \cdot 242$ & $0 \cdot 135$ & 0.063 & $0 \cdot 486$ & $0 \cdot 476$ & $0 \cdot 107$ & \\
\hline 16, & $1 \cdot 26$ & $0 \cdot 216$ & 0.081 & $0 \cdot 168$ & $0 \cdot 742$ & $0 \cdot 124$ & $0 \cdot 135$ & 0.01 \\
\hline
\end{tabular}

It will be noticed from the analysis of the blank that the original dry gelatin contains roughly 50 per cent. of matter precipitable by Stutzer's reagent, so-called albumoses. In the early stages these albumoses seem to be first attacked by the organism; but subsequently their decomposition proceeds at an equal rate with that of the true gelatin.

A notable feature in this research is the small production of ammonia and volatile bases, in view of the fact that substances such as trimethylamine, indol, and skatol have been generally stated in analyses by other observers to be constant accompaniments of the liquefaction of proteids. That this is not accounted for by the volatilization of such bodies during the incubations is proved by the comparative absence of odour and of strong alkaline reaction in the air of the flasks, and in such loss not being indicated by the total nitrogens. Previous investigations have, however, been conducted with "nutrient gelatin," containing other proteids. The quantity of ammonia produced is insignificant, amounting, even after sixteen days' incubation with $B$. fluorescens liquefaciens, to only 0.168 gramme of nitrogen per 100 c.c., corresponding to $0 \cdot 204$ gramme of ammonia.

The figures for the nitrogen unaccounted for, which would be almost entirely peptones, are very interesting. The original gelatin solution containing 0.069 gramme per 100 c.c., this gradually increases as the liquefaction proceeds, until, with $B$. fluorescens liquefaciens, it reaches the maximum figure of $0 \cdot 476$, when the medium is just entirely liquefied, and then diminishes, after sixteen days, to $0 \cdot 124$, showing that the bacillus, after bringing about the decomposition of nearly all the gelatin and albumoses, subsequently attacks the peptone, which has meanwhile been produced, with a corresponding increase of bases and extractives soluble in alcohol.

It is known that certain bacteria produce peptonizing enzymes, and in the case of the $B$. fluorescens liquefaciens the organism appears, as shown above, to subsequently feed on the peptone produced by its enzyme.

In order to ascertain whether the enzyme is capable of liquefying the gelatin 
without the aid of bacteria, a large quantity of gelatin medium was inoculated with B. flworescens liquefaciens, and incubated at $20^{\circ} \mathrm{C}$. After about five days, when the culture was entirely fluid, some of it was filtered, by a vacuum, through a Pasteur candle into a filtering-flask containing 100 c.c. of 10 per cent. gelatin that was quite sterile. When about 10 to 15 c.c. of the culture had passed through, the filter was removed, the neck of the flask plugged with cotton-wool, and the gelatin warmed to $30^{\circ} \mathrm{C}$, so as to be able to mix the filtrate uniformly with the gelatin solution; it was then allowed to set quite firmly, and incubated at $20^{\circ} \mathrm{C}$. As after a few hours the gelatin was not quite solid, it was removed from the incubator and kept in a room at about $10^{\circ} \mathrm{C}$. In twenty-four hours the contents of the flask were semiliquid, and after thirty-six hours quite liquid. It was proved to be sterile by microscopical examination and by attempts at subculture. The liquid did not smell putrid, and was not fluorescent; except that it was liquid, it appeared the same as the original gelatin solution. The contents of the flask were then analysed with the following results, calculated into grammes of nitrogen per 100 c.c. :

\begin{tabular}{|c|c|c|c|c|c|}
\hline $\begin{array}{c}\text { Total } \\
\text { Nitrogen. } \\
1.232\end{array}$ & $\begin{array}{c}\text { Gelatin. } \\
\cdot 359\end{array}$ & $\begin{array}{c}\text { Albumoses. } \\
0.21\end{array}$ & $\begin{array}{c}\text { Ammonia. } \\
\text { Nil }\end{array}$ & $\begin{array}{c}\text { Bases and } \\
\text { Extractives. } \\
0.469\end{array}$ & $\begin{array}{c}\text { Peptone. } \\
0.174\end{array}$ \\
\hline
\end{tabular}

The liquid was tested for the presence of peptone by dialysing a portion, and adding caustic soda and copper sulphate to the dialysate, when a strong biuret reaction was obtained; with the original gelatin solution similarly treated there was no reaction. That an enzyme is produced by $B$. fluorescens liquefaciens was further confirmed by repeating the above experiment on 15 per cent. gelatin containing Pasteur's solution as before, but not alkalized, when it was found to be liquefied in twenty hours at $17^{\circ}$ to $18^{\circ} \mathrm{C}$. 